\title{
Between Charlemagne ande Atlantis: Belgium and the Netherlands during the first stages of European Integration (1950-1966)
}

\author{
Skander NASRA and Mathieu SEGERS
}

During the late 1940s, the unfolding Cold War and the devastating economic situation in Europe led to multiple schemes and designs aimed at pulling off regional economic cooperation in Western Europe. ${ }^{1}$ Strong impulses for the creation of a 'European economic federation' came in particular from Washington. In a memorandum of May 1947 to Secretary of State George Marshall, Under Secretary of State for Economic Affairs William Clayton argued that US aid should be supported by 'a European plan' for such a 'European economic federation' because Europe would be unable to recover from the war as long as its economy continued 'to be divided into many small watertight compartments as it is today'. Clayton pointed at an evident best practice: the emerging Economic Union between Belgium, the Netherlands and Luxemburg, the Benelux. ${ }^{2}$

The Benelux had been in the making since 1944, when the three governments in exile in London had agreed to deepen their monetary cooperation in the form of a Customs Union that came into effect on 1 January 1948. According to many, this example of regional integration represented the 'test laboratory' for future European integration. ${ }^{3}$ The emerging Benelux, which was essentially based on Belgian-Dutch (economic) rapprochement and aimed at establishing a common external tariff, set an example of how the post-war Western European economies could speed up their recovery and ipso facto could multiply their political weight in European and international relations.

This traditional image of the Benelux as a forerunner of European integration dominates the historiography of European integration. According to this view, the Benelux represents an effective policy instrument within the process of European integration that enables the three countries to assert disproportional influence in re-

1. Skander Nasra currently works for the Belgian Ministry of Foreign Affairs. The views expressed in this article only reflect those of the authors, and do by no means bind the Belgian Ministry of Foreign Affairs.

2. Cited in: D. DINAN, Europe Recast. A History of European Union, Palgrave, Basingstoke, 2004, pp. 25-26; See also E. VAN DER BEUGEL, From Marshall Aid to Atlantic Partnership, Elsevier, Amsterdam, 1966, p.76. Belgium and Luxembourg were in an economic union since 1922 (Belgium Luxembourg Economic Union, BLEU). Originally, the Benelux cooperation was focused on the levelling out of balance of payments imbalances and joint strengthening of economic recovery. The (bilateral) Customs Union would transform in a full-fledged (multilateral) Economic Union on 3 February 1958.

3. A.G. HARRYVAN, In Pursuit of Influence. The Netherlands' European Policy during the Formative Years of the European Union, 1952-1973, Peter Lang, Brussels, 2009, p.99; D.A. HELLEMA, Buitenlandse Politiek van Nederland, Het Spectrum, Utrecht, 2006, p.117. 
lation to their more powerful neighbours. Consequently, the considerable potential of the Benelux in terms of power accounts for the traditional pro-European policies of Belgium and the Netherlands. The famous Benelux memorandum, which functioned as the blueprint for the Resolution of Messina (1955) and formed the basis for the Rome Treaties (1957), still counts as the ultimate proof of the potential impact of intimate Belgian-Dutch cooperation in European affairs. ${ }^{4}$ This has strengthened an image of highly effective Belgian-Dutch cooperation during the formative years of European integration.

Relatively recently, historians have balanced this image. Since the declassification of relevant archives, the articles and books of Yves Stelandre, Richard Griffiths and Anjo Harryvan contributed greatly to the de-mystification of the successes of the Belgian-Dutch partnership during the first decades of European integration as well as of its supposed rational choice groundwork. These scholars have argued that, in contrast to the traditional picture, tenacious Belgian-Dutch disagreement, divergent Belgian and Dutch economic goals, as well as institutional vagueness were at least as consistent characteristics of the Belgian-Dutch partnership within Benelux, as were their famous concerted lobbying efforts to the benefit of the relance européenne in the mid-1950s. ${ }^{5}$

In this article we confirm the earlier revisionist conclusions of Stelandre, Griffiths and Harryvan and aim at taking the research a step further. Whereas their research has been focused on episode or country specific case studies - the Benelux countries and the Fouchet negotiations (Stelandre) and Dutch European policy within the Benelux framework during the 1950s (Griffiths and Harryvan) - this article adds two new elements in order to deepen the analysis of the cooperation. First, we outline the

4. See also T. JUDT, Postwar. A history of Europe since 1945, The Penguin Press, New York, 2007, pp.155 and 302; J. GILLINGHAM, European integration 1950-2003. Superstate or New Market Economy?, Cambridge University Press, Cambridge, 2003, p.45; A. MORAVCSIK, The Choice for Europe. Social Purpose and State Power from Messina to Maastricht, Cornell University Press, Ithaca/New York, 1998, p.142; W.H. SALZMANN, Herstel, wederopbouw en Europese samenwerking, Sdu Uitgevers, Den Haag, 1999, p.257. The narratives of effective Benelux cooperation and the disproportional influence of Belgium and the Netherlands in (early) European integration have been nourished by the memoirs of some prominent Belgian and Dutch policy-makers (D.U. STIKKER, Men of Responsibility. A Memoir, John Murray, London, 1965; J.C. SNOY ET D’OPPUERS, Les étapes de la coopération Européenne et les négociations relatives à une zone de libre échange, in: Chronique de Politique Étrangère, 7(1959), pp.569-623; C. RUTTEN, Aan de wieg van Europa en andere Buitenlandse Zaken, Boom, Amsterdam, 2006, p.35. For a more elaborate overview of the traditional historiography on the Benelux see: A. G. HARRYVAN, op.cit., pp.99-101.

5. Y. STELANDRE, Les pays du Benelux, l'Europe politique et les négociations Fouchet (26 juin 1959-17 avril 1962), in: Journal of European Integration History, 2(1996), pp.21-38; R.T. GRIFFITHS (ed.), The Netherlands and the integration of Europe, NEHA, Amsterdam, 1990, pp.20-29; A.G. HARRYVAN, A.E. KEESTEN, The Netherlands, Benelux and the Relance européenne 1945-55, in: E. SERRA, La relance européenne et les traités de Rome, Bruylant, Brussels, 1989, pp.125-157; A. HARRYVAN, op.cit., pp.99-147. For a recent and extensive elaboration of the diverging Belgian and Dutch economic interests concerning agriculture and the opposite policies, in which this divergence resulted see: A-C.L. KNUDSEN, Farmers on Welfare. The Making of Europe's Common Agricultural Policy, Cornell University Press, Ithaca, 2009, pp.89-100. 
patterns of discord at work behind the Benelux partnership. Second, we broaden and lengthen the span of research by incorporating the main stages during the entire period of the formative years of European integration (1950-1966). The article is based on new bi-national archival research and is complemented by a close reading of existing Dutch language literature and ego-documents.

The central question of this article is the following. If there was only a limited congruence of Belgian-Dutch interests during the formative years of European integration and if the relations between Brussels and The Hague were often hindered by fundamental disagreements, then what did support the emerging Belgian-Dutch partnership? After all, close Belgian-Dutch cooperation did exist during certain crucial episodes of European integration, for instance during the above-mentioned phase of the relance in 1955 or in the run-up to the failure of the Fouchet plan in 1962, to name but two well-known examples.

This article is structured as follows. In the following three sections we describe the Belgian-Dutch cooperation during the negotiations over the European Coal and Steel Community (ECSC), the European Defence Community (EDC) and the European Political Community (EPC) (sections two, three and four). In the fifth, sixth and seventh section we look into the Belgian-Dutch initiatives aimed at reinvigorating European integration as of the mid-1950s. Here, particular attention is given to what turns out to be an exceptional episode of intense cooperation, initiated by the Belgian Minister of Foreign Affairs, Paul-Henri Spaak and his Dutch counterpart Jan-Willem Beyen. In the last two full sections (sections eight and nine), we analyse the Belgian and Dutch efforts to challenge de Gaulle's attempts to establish a 'European Europe' based on the General's European Political Union (EPU) initiative (the Fouchet Plan). In the final section we sum up the main conclusions.

\section{The threat of supranational integration and the instrument of cooperation}

On 9 May 1950, Belgium and the Netherlands were taken by surprise. On that day, Robert Schuman, Foreign Minister of France, proposed to pool the coal and steel production of European countries and to reside it directly under the auspices of a supranational authority. This revolutionary French initiative had been scrupulously kept secret. Only the West German Chancellor Konrad Adenauer was informed beforehand. The careful timing of the launch of the plan was mirrored in the positive reaction in public opinion. ${ }^{6}$

6. Archive of the Dutch Ministry of Foreign Affairs, The Hague (NArch), Foreign Affairs, 6, 1945-54, 996.1., 09.06.1950. 
However, the Belgian and Dutch governments reacted with great reluctance. ${ }^{7}$ The Schuman Plan raised fundamental questions for the two countries. How would the future supranational entity relate to the (private) Belgian and Dutch economic interests? What implications would supranational integration have with regard to the position of the smaller member states of the future organisation? And what if the "new Europe' remained continental, excluding the United Kingdom? What if it neglected Europe's Atlantic bonds in the mid to long term? There was, however, little time to reflect on these existential questions. Given the economic dependence of Belgium and the Netherlands on their neighbouring markets, it was simply impossible for both countries to ignore the Schuman Plan.

The inevitability of Belgian and Dutch participation in the Schuman Plan did not cancel out their concerns. On the contrary, both governments remained highly sceptical, especially with regard to the centrepiece of the plan, the supranational High Authority. ${ }^{8}$ The uneasy feeling was reinforced during talks between the Economics Ministers of the Benelux countries and Schuman and Jean Monnet. Indeed, the two Frenchmen convincingly put forward the political advantages of their plan, but its institutional consequences seemed to be 'less thought through', as the Dutch Minister noted afterwards. The High Authority, to which participating countries were asked to delegate their policy autonomy in the fields of coal and steel, would be accountable to no one. This was undesirable, as it seemed plausible that the High Authority would exercise direct influence over crucial aspects of domestic policy-making such as wages and prices. Furthermore, the issue of British participation remained unaddressed during the conversation of the Benelux Ministers with the French initiators of the plan. Even if Schuman and Monnet were sincerely hoping that the UK would join the negotiations (as they claimed), it would be far from the conditio sine qua non that especially The Hague wanted it to be. Shuman and Monnet had made it unmistakably clear that they felt that a possible British rejection of an invitation should not prevent the six continental countries from making progress in European integration. ${ }^{9}$

7. The British envoy to the OEEC described the spontaneous reaction of the Dutch Minister of Foreign Affairs Dirk Stikker as 'obviously perturbed' (cited in: A.E. KERSTEN, A Welcome Surprise? The Netherlands and the Schuman Plan Negotiations, in: K. SCHWABE, Die Anfänge des SchumanPlans 1950/51, Nomos, Baden-Baden, 1998, p.285).

8. J.-C. Snoy et d'Oppuers. Cabinet note for the Council of Ministers, 25.05.1950, in: G. KURGANVAN HENTENRYK, I. SIRJACOBS, Belgische diplomatieke stukken 1941-1960. Deel IV-Europa: economische aspecten, Koninklijke Vlaamse academie van België voor wetenschappen en kunsten, Brussels, 2001, pp.303-307; NArch, 2.02.05.02 (Arch MR), 394, DBNEI/ing, 22.05.1950.

9. NArch, 2.02.05.02 (MR), 394, Spierenburg to M. (report of the talk between the Ministers of Economy of the Benelux-countries with Schuman and Monnet, 24.05.1950); Interview with D.P. Spierenburg, in: A.G. HARRYVAN, J. VAN DER HARST, S. VAN VOORST, Voor Nederland en Europa. Politici en ambtenaren over het Nederlandse Europabeleid en de Europese integratie, 1945-1975, Boom, Amsterdam, 2001, p.268. 


\section{Intergovernmental safeguards within the ECSC}

The positions of Belgium and the Netherlands during the ECSC negotiations differed substantially. In the light of the political importance that France and Germany attributed to the Schuman Plan, Belgian policy-makers refrained from taking a too principled stand with regard to the supranational features of the plan and the possible political integration that could spring from it. ${ }^{10}$ The Belgian delegation preferred to battle for compensations for those domestic industrial sectors that were threatened most by the intensified intra-European competition inherent in the plan. ${ }^{11}$ Even though Belgium was convinced that political cooperation must result from economic cooperation (and not the other way around), ${ }^{12}$ it decided to react cautiously in order to prevent a too direct confrontation with Paris and Bonn. Furthermore, the reticent attitude of the Belgian delegation concealed differences of opinion within the ruling Christian democratic governments of Jean Duvieusart and Joseph Pholien, as well as within the liberal and socialist opposition. While proponents of the Schuman Plan emphasized its commercial advantages, its opponents were wary of possible interventionist tendencies of the new supranational body, which could imply the hollowing out of national sovereignty. It should be noted however, that the ECSC talks incited only little interest within the Belgian political elite and public opinion. At the time, the public debate was dominated by the political tensions surrounding the succession of King Leopold III by his son Baudouin. Against this background, it was essentially up to the Minister of Foreign Affairs, Paul van Zeeland, to define the Belgian position. His position boiled down to a defensive stance regarding state sovereignty: neither interventionist European policies nor the hollowing out of national sovereignty were acceptable. ${ }^{13}$

The Netherlands took a more proactive approach. Within the framework of the Organisation for European Economic Cooperation (OEEC), the Dutch government Drees-Van Schaik, a coalition of both Catholic and Protestant Christian-Democrats (KVP and CHU), Liberals (VVD) and Socialists (PvdA), launched a full-fledged counterproposal named after the Dutch Foreign Minister, VVD's Dirk Stikker. ${ }^{14}$ The plan proposed liberalisation schemes per sector within the OEEC zone (thus including the UK), accompanied by additional measures (of social policy) to compensate for frictional unemployment and/or temporal capital losses. These proposals had been circulated in the Dutch government circles well before the launch of the Schuman

10. Although the Belgians largely shared the Dutch concerns, especially with regard to the supranational aspects of the plan (Archives of the Belgian Ministry of Foreign Affairs (BelArch), 5216, Belgian delegation to the Schuman Plan, 20-24.06.1950.

11. F. Muuls. Belgian delegation to the negotiations of the Schuman Plan, 18.08.1950, in: G. KURGANVAN HENTENRYK, I. SIRJACOBS, op.cit., pp.317-318.

12. Belgian Ministry of Foreign Affairs. Report of the meeting of the Belgian delegation with the Minister of Foreign Affairs, P. van Zeeland, 29.06.1950, in: G. KURGAN-VAN HENTENRYK, I. SIRJACOBS, op.cit., pp.314-15.

13. R. COOLSAET, België en zijn Buitenlandse Politiek 1830-2000, Van Halewijck, Leuven, 2001, pp.389-391.

14. D.A. HELLEMA, op.cit., pp.162-163. 
Plan. ${ }^{15}$ However, at the time Stikker launched his proposal, the strict intergovernmental nature of his initiative had become outdated in comparison to the more encompassing approach of the revolutionary Schuman Plan. The Netherlands had no choice but to come to terms with this reality, in which their plans were relegated to the realm of old politics.

This was not an easy thing to do. It led to increasing tensions within the Dutch cabinet, which was strongly divided over the Schuman Plan. Sceptics such as Prime Minister Willem Drees and Minister of Finance Pieter Lieftinck (both PvdA), who rejected the Schuman Plan out of hand, faced the Ministers of Economy and Agriculture, ${ }^{16}$ Jan van den Brink (KVP) and Sicco Mansholt (PvdA), who embraced the French initiative. Stikker (VVD) took a mid-path position. He indeed considered the Schuman Plan to be anything but a desirable mode for economic cooperation in Western Europe, but on the other hand judged the initiative a 'necessary evil' to solve the urgent and primary 'German problem'. Nevertheless, the instructions for the Dutch delegation in the ECSC negotiations tended towards a rejection of all supranational aspects of the Schuman Plan. The Dutch feared that the ECSC would prelude a protectionist 'little Europe' dominated by France and Germany. Such a scenario risked estranging continental Western Europe from its Atlantic allies. This, of course, was a nightmare for the arch-Atlantic Dutch. But there was more to fear. If the Schuman Plan was the blueprint for future European integration, the ECSC paved the way for a Franco-German directorate in Western Europe, equipped with supranational instruments by which it could meddle with domestic politics, possibly also interfering with Dutch low wage policies which constituted the linchpin of the Netherlands' economic recovery program. ${ }^{17}$

In this context, Belgian-Dutch cooperation within the framework of the Benelux offered Brussels and The Hague the opportunity to join forces. By working together, they could reinforce their shared scepticism towards the supranational integration plans and substantiate their plea for a more Atlantic organisation. Their joint efforts aimed at both the establishment of a (intergovernmental) Council of Ministers as a counterweight to the foreseen High Authority of the ECSC and the creation of the possibility to lodge an appeal against decisions of this supranational entity. ${ }^{18}$

15. NArch, Working program for the memorandum regarding European integration, no date, DBNEI/ ing; NArch, Preparations Stikker Plan via REA, 2.02.05.02 (Arch. MR), 586, DBNEI/ing.

16. Interview with D.P. Spierenburg, in: A.G. HARRYVAN, J. VAN DER HARST, S. VAN VOORST, op.cit., p.268.

17. A.E. KERTSEN, op.cit., pp.287-291. The skeptical attitude of the cabinet, which resulted from the negative stance of Drees and Lieftinck, was only poorly reflected in the constructive attitude of the Dutch delegation, which was led by Spierenburg of the Ministry of Economic Affairs (and later the first Dutch Commissioner in the High Authority of the ECSC) and Max Kohnstamm of the Ministry of Foreign Affairs (and later personal advisor to Jean Monnet and Secretary general of Monnet's Action Committee).

18. Belgian Ministry of Foreign Affairs. Report of the reunion of the Belgian delegation and Minister of Foreign Affairs Paul van Zeeland, 29.06.1950, in: G. KURGAN-VAN HENTENRYK, I. SIRJACOBS, op.cit., pp.314-315. 
Notwithstanding this joint endeavour, diverging economic objectives prevented Belgium and the Netherlands from fixing a general common Benelux stance in reaction to the Schuman Plan. And there were reasons for this. First, Belgium was a traditional steel exporter with a large and influential steel sector loaded with vested interests and characterised by relatively high production costs, ${ }^{19}$ while the Netherlands imported most of its steel and was in the midst of the build-up of a modern and competitive steel sector. ${ }^{20}$ Second, the Netherlands feared an upward tendency regarding prices and wages as a result of the harmonisation processes implicit in the pooling of coal and steel production. This would undermine the competitiveness of the Dutch export economy that was in the midst of a rebuilding process, recovering of a hard war. ${ }^{21}$ The Belgian economy, in contrast, had come out of the war only moderately weakened, and therefore - diametrically opposed to Dutch concerns feared a race to the bottom in terms of wages and prices. The expensiveness and low profits of the Belgian coal sector was a telling sign of the vast financial means of the Belgian treasury. This was all illustrative for the already well-established Belgian welfare state. All in all, it did not need to surprise that the Belgian government was afraid of negative repercussions of the Coal and Steel Community with regard to its national system of social security and the management of Belgian businesses. ${ }^{22}$

Driven by a shared aversion to supranational integration, Belgium and the Netherlands cooperated effectively and managed to temper the supranational aspects of the Schuman Plan. ${ }^{23}$ The establishment of the Council of Ministers as an official ECSC institution was a major accomplishment in that respect. As one of his top-negotiators would declare afterwards, it constituted 'an absolute necessity' for the Dutch Prime Minister Drees to agree to the final results of the ECSC negotiations. ${ }^{24}$ On 25 July 1952 , the ECSC Treaty entered into force with Belgium and the Netherlands on board. By that time, the ECSC was however no longer the only 'European community' in the making.

19. A.S. MILWARD, The European Rescue of the Nation-State, Routledge, London, 1994, pp.50-64.

20. A.E. KERSTEN, op.cit., p.292.

21. D.A. HELLEMA, op.cit., p.153.

22. M. Suetens. Belgian delegation to the negotiations of the Schuman Plan, 05.09.1950 and Ministry of Economy, Note on the Schuman Plan, 17.06.1950, in: G. KURGAN-VAN HENTENRYK, I. SIRJACOBS, op.cit., pp.318-319 and 307-310. See also R.T. GRIFFITHS, De Benelux-landen en het Schuman-plan, in: E.S.A. BLOEM (ed.), Het Benelux-effect, Boom, Amsterdam, 1992, pp.74-84.

23. The Belgian delegation emphasized the crucial importance of the alliance of the Benelux-countries during the negotiations of the ECSC, especially regarding the political aspects of the Schuman Plan (F. Muuls, 18.08.1950, op.cit.).

24. Interview with D.P. Spierenburg, in: A.G. HARRYVAN, J. VAN DER HARST, S. VAN VOORST, op.cit., p.269. 


\section{EDC: shared concerns and painful pragmatism}

The outbreak of the Korean War in the summer of 1950 had put the precarious issue of West German rearmament on the top of the Western bloc's political agenda. The main reason for this was a pressing American request to rearm West Germany. In an attempt to make a virtue of necessity, France had proposed to set up a common European army - bringing small national military units under the leadership of a supranational body (residing under a European Minister) - which could provide a longlasting solution to the problem of German rearmament modelled on the ECSC, the European project that had enabled Paris to keep control over West Germany's economic powerhouse in the Ruhr. On 24 October 1950, the French Minister of Defence, René Pleven, revealed the new European project of the EDC. In May 1952, the Treaty of the EDC was signed. This sparked additional talks about a European Political Community (EPC). The EDC would, however, never enter into force. On 30 August 1954, after months of crisis negotiations and feet dragging, the French Parliament wrecked the treaty. ${ }^{25}$

Belgium and the Netherlands had led a strong campaign against the EDC, mainly fuelled by fear of future domination by the 'big three' (France, Germany and Italy). ${ }^{26}$ This fear had been reinforced since the EDC would bring European integration into the realm of high politics. ${ }^{27}$ Because of its supranational character, the EDC, just like the ESCS earlier, was perceived mainly as a threat for the small partners among 'the Six'. Again, Belgium and the Netherlands found each other in fearful scepticism and coordinated their positions within the framework of a Benelux commission. However, behind this veil of intense cooperation, the Belgian and Dutch positions diverged starkly, both in terms of content and strategy.

Belgium gradually toughened its opposition to the supranational aspects of the EDC. In line with its position during the ECSC talks, the Christian democratic government Pholien feared that the EDC would undermine national sovereignty to an unacceptable extent and would further weaken Belgium's position vis-à-vis its neighbours. Whereas Belgium initially focused on combating the supranational elements of the EDC, the Netherlands grew increasingly concerned with the reality of 'little Europe' as such. Deep down the Dutch felt they did not belong to the continental

25. The EDC and West-German rearmament were inextricably linked. Therefore, the EDC was a precondition for the entry into force of the so-called Deutschlandvertrag, which foresaw the legal rehabilitation of West Germany. For the follow-up to the Deutschlandvertrag after the failure of the EDC, see: Dokumente zur Deutschland-Politik, II Reihe (4), Die Außenminister-Konferenzen von Brüssel, London und Paris 8. August bis 25. Oktober 1954, München, 2003.

26. It should be noted however that the Belgium government by 1954 had completed a quite spectacular turnaround. In April 1954, the socialist-liberal coalition under Premier van Acker, under strong impulses from Spaak, made an ultimate effort to save the EDC-project. See M. Dumoulin, Spaak, Racine, Brussels, 1999, pp.468-470.

27. J. Pholien, Intervention at the Conference of the Ministers of the Benelux, 25.10.1951, in: L. DE VOS, P. DELOGE, E. ROOMS, J.-M. STERKENDRIES, Belgische diplomatieke stukken 1941-1960. Deel II - Defensie, Koninklijke Vlaamse Academie van België voor Wetenschappen en Kunsten, Brussels 1998, p.301. 
grouping of the ECSC, dubbed a 'relatively small protectionist club' by Prime Minister Drees. ${ }^{28}$ These Dutch preoccupations were difficult to grasp for the Belgians, as were the Dutch anxieties with regard to a future division of Western Europe resulting from the continued absence of the UK in the European integration process.

According to Dutch doomsday scenarios, which appeared more and more realistic as European integration deepened, a more Atlantic British-Scandinavian project would soon rival the continental Franco-German Europe of 'the Six' ${ }^{29}$ In a suchlike scenario, the arch-Atlantic Dutch would not only find themselves locked in the wrong bloc (the continental 'Six'), but the unity within the North Atlantic Treaty Organization (NATO) would come under pressure too. In Dutch eyes, NATO was and should remain the uncontested lead organisation of the West. These grave concerns were a sufficient reason for the Dutch government to turn down the Pleven Plan altogether.

This was not done easily. This euro-sceptic course, after all, was completely at odds with the pro-EDC position of Washington as well as with the dominant sentiment in the Dutch Parliament. As had been the case with regard to the ECSC, the uneasy position of the government was reflected in a deeply split Dutch cabinet, cross-cutting the governing parties and dividing its Ministers in three more or less equal fractions: traditional 'free traders' (like Prime Minister Drees), 'modern' Atlanticists, propagating some kind of (intergovernmental) confederation (like Stikker and a majority of the foreign policy elite), and 'pro-little Europe' federalists (like Mansholt and most of the KVP and PvdA parliamentarians). ${ }^{30}$ The enduring fragmentation of the cabinet on the issue of the future of European integration left the formulation of Dutch European policy increasingly in disarray. Consequently, the Dutch government remained unable to take a strong and consistent stance in the EDC negotiations and chose to take part in the talks as an observer only.

The Dutch aloofness strained Belgian-Dutch relations. Not in the least, because it left the dirty work - to oppose the undesirable French plans - to Belgium. ${ }^{31}$ With the Belgians irritated by the Dutch absence during the first round of talks and The Hague increasingly distrustful due to the ambiguous position of Belgian Foreign Minister van Zeeland and the supposed dominant francophone influence in Belgian foreign policy, mutual suspicion grew steadily. ${ }^{32}$

However, as from the autumn of 1951 onwards, Belgian and Dutch views slowly converged as a result of a changing Dutch position. Under strong American pressure,

28. Cited in: J. VAN MERRIENBOER, Mansholt, Boom, Amsterdam, 2006, p.234. See also NArch 1965-74/16196, De Koster to MP, 12.12.1967.

29. J. VAN DER HARST, The Netherlands and the EDC, EUI Working Paper, 252, 1986, pp.3-9.

30. Compare R. GRIFFITHS, A.S. MILWARD, The Beyen Plan and the European Political Community, in: W. MAIHOFER (ed.), Noi si mura, European University Institute, Badia Fiesolana, 1986, pp.600-604; C. PARSONS, Showing Ideas as Causes: The Origins of the EU, in: International Organization, 1(2002), pp.57-58.

31. J. VAN DER HARST, The Netherlands ..., op.cit., pp.8-9. The fall of the cabinet supplied an easy argument. J. VAN DER HARST, Nabuurstaten of uniepartners? Aspecten van het defensiebeleid van de Benelux-landen, 1945-1954, in: E.S.A. BLOEMEN (ed.), op.cit., pp.134-135.

32. J. VAN DER HARST, The Netherlands ..., op.cit., p.17. 
the Dutch delegation reversed its observer status and decided to participate in the EDC negotiations. This allowed Belgium to toughen its EDC wary position. Besides its somewhat artificial constitutional objections, ${ }^{33}$ Belgium could now give way to its aversion to a 'political Europe' dominated by France and Germany, something that could only marginalise the small member states among 'the Six' and had thus to be avoided by all means. ${ }^{34}$ The Netherlands couldn't agree more. After it had joined the negotiations, intense consultations with Brussels were set up in order to fine-tune the Low Countries' opposition to the EDC. In October 1951, an inter-ministerial Benelux conference further strengthened Belgian-Dutch collaboration, which would nearly succeed in bringing down the EDC.

By the end of 1951, a clash between the Benelux countries and the 'big three' dominated the EDC negotiations. Belgium and the Netherlands jointly opposed the proposed common budget and common armament program. Like during the ECSC negotiations, they pleaded for the establishment of a Council of Ministers, to counterbalance supranational tendencies, and for unanimity voting, which was still seen as the ultimate instrument to protect the position of small member states..$^{35}$ In addition, both countries underlined the necessity of strong institutional bonds with NATO. Initially, this all seemed to no avail, as Belgium and the Netherlands had to concede and, eventually, to accept the establishment of the EDC under strong US pressure. ${ }^{36}$

Hard-fought opposition, nevertheless, had born some fruit. The idea of a European Defence Minister had been dismissed, the supranational capacities of the EDC were not as far-reaching as those of the ECSC, the competences of the Council of Ministers were extended (in fact making it the central decision-making authority within the community method), all decisions were to be taken by unanimity, 'safeguarding a maximum of national sovereignty', ${ }^{37}$ and, last but not least, the EDC units were to be subordinated to NATO. ${ }^{38}$ From a Belgian perspective, consistent opposition against the supranational features of the EDC eventually had led to considerable concrete results. From a Dutch perspective things looked slightly different. The Netherlands had not really been able to substantially influence the outcome, as it had been limited to act within the framework of the already existing Belgian opposition and merely had facilitated its toughening. In comparison to Brussels, a divided The

33. In order to give up competences to a supranational entity, Belgium would have to change its constitution first. This would not only create an additional delay for several months, it would risk reinforcing internal political contradictions. Despite the legal argumentation, Belgium had already signed and ratified the ECSC Treaty, which also implied far-reaching transfers of competences.

34. J. VAN DER HARST, Nabuurstaten ..., op.cit., pp.136-137; R. COOLSAET, op.cit., pp.394-97; L. DE VOS, P. DELOGE, E. ROOMS, J.-M. STERKENDRIES, op.cit., pp.313-315.

35. J. Papeians de Morchoven, Note to the Minister, 21.12.1951, in: L. DE VOS, P. DELOGE, E. ROOMS, J.-M. STERKENDRIES, op.cit., p.306.

36. Summary of the Conference of the Ministers of the Benelux-countries, 25.10.1951, in: L. DE VOS, P. DELOGE, E. ROOMS, J.-M. STERKENDRIES, op.cit., pp.297-302; J. Papeians de Morchoven, op.cit.

37. Belgian Ministry of Foreign Affairs, EDG. Synthese, 16.04.1953, in: L. DE VOS, P. DELOGE, E. ROOMS, J.-M. STERKENDRIES, op.cit., 348-351.

38. R. COOLSAET, op.cit., p.397. 
Hague largely had been overtaken by events: it had been forced to drop its observer status due to overwhelming pressure from Washington. ${ }^{39}$ The successful partnership with Belgium had never been more than an undesired, yet inevitable, option B.

The example of the EDC negotiations characterises the Belgian-Dutch partnership. It is illustrative that once the EDC treaty was signed, close cooperation within the Benelux framework almost immediately became problematic. Eager to court its American friends, the Netherlands wanted to be the first country to ratify the EDC treaty. The Belgian Ambassador to The Hague subtly noted that the strong American support for the EDC had urged the Netherlands to transform its initial hostile position into a most favourable stance towards the EDC. ${ }^{40}$ In other words: the Dutch left little doubt about their preparedness to subordinate their reluctance regarding supranational European integration to Dutch-American relations. This had not much to do with a commitment to the Belgian-Dutch partnership.

In Brussels, however, things appeared to work the other way around. The Belgian scepticism, reflected in a rather vague position of opposing the EDC, proved far more consistent than the Dutch chicaning spurred by American pressures. Despite concessions of France and Germany, van Zeeland remained unconvinced of the desirability of the EDC, which led to a particularly strenuous ratification process in Belgium. It even urged Monnet to warn the US Secretary of State, Dean Acheson, that next to the UK the most serious obstacles to future European unity were to be expected to come from Belgium. However, in the end, Brussels was no match for Washington. Belgium refused to give in until the US threat to end bilateral military cooperation. Looming isolation within the Western bloc and a personal intervention by President Dwight D. Eisenhower ultimately won over van Zeeland for the EDC and forced the Belgian Parliament to ratify the EDC treaty in the autumn of $1953 .{ }^{41}$

\section{EPC: Towards a reinterpretation of supranational integration}

The Low Countries' fear for marginalisation in a political version of 'Little Europe' repeatedly came to the forefront during the negotiations over EPC (which took place within the framework of the EDC talks, with regard to article 38). Belgium emphasised its preference for a community of states over some sort of a federal or confederal

39. J. VAN DER HARST, The Netherlands ..., op.cit., p.29.

40. In addition, the Netherlands was strongly opposed to the French wish to set up a political authority before ratifying the EDC treaty. The Netherlands did not consider the creation of the EPC opportune given the weak economic integration of Europe.

41. Belgian Ministry of Foreign Affairs, Summary of the meeting of US President Eisenhower and Minister van Zeeland, 16.03.1953 and Belgian Ambassador in Washington to Paul van Zeeland, 24.06.1953, in: L. DE VOS, P. DELOGE, E. ROOMS, J.-M. STERKENDRIES, op.cit., pp.336-337 and 351-53; J. E. HELMREICH, United States Relations with Belgium and the Congo 1940-1960, University of Delaware Press, Newark, 1998, pp.121-127. 
Europe. ${ }^{42}$ For both Belgium and the Netherlands, the prevailing sentiment remained unchanged: an intergovernmental organisation represented the best guarantee to preserve the position of small states..$^{43}$ Both countries shared the wish to establish a European common market before setting up any European political construct.

After the signing of the EDC treaty, the Netherlands would gradually become the proactive champion of the common market project. Already on 10 March 1952, the Netherlands had launched the so-called Beyen Plan (named after the Dutch Minister of Foreign Affairs, Jan-Willem Beyen) as input for the EPC talks. The plan aimed at establishing a common market. However, it lost momentum in the course of 1954 due to the dragging ratification process of the EDC. ${ }^{44}$ But the ideas of Beyen would resurface in 1955, within the framework of the initiatives of Spaak and Monnet to revive European integration after the debacle of the EDC.

Fear of future domination by France and Germany remained a common constant factor in Belgian and Dutch European policies. Yet, as both countries continued to bring their policies in line with the evolving reality of European integration among 'the Six', they changed their analysis with regard to supranational integration. The analyses underpinning their respective European policies developed in similar proEuropean directions: supranational integration was less and less seen as a threat to the small members of 'the Six'. Both Brussels and The Hague, although in different ways, came to the conclusion that continued resistance against supranational integration would mean fighting a rearguard battle. Moreover, given the path of European integration chosen with the ECSC, active support for (supranational) European integration was probably the best way to counter forces in favour of the emergence of a Franco-German directorate, which remained their main concern regarding the integration process. It was more and more seen as a chance to safeguard the influence of small member states. Notwithstanding this parallel development in their vision of the integration process, the Low Countries, however, would remain unable to develop a genuine partnership in European affairs - although at first glance history may suggest the opposite.

42. BelArch, Note to the Minister, 17771/1.

43. The Belgian and Dutch positions were coordinated in order to strive for (1) the establishment of a common market, (2) a legislative power that had to consist of two chambers - with one chamber composed of a parity of elected representatives or members of government -, and (3) an executive power attributed to a college presided by a rotating presidency avoiding a too strong position for the President. Belgian Ministry of Foreign Affairs, Talks between Minister of Foreign Affairs Paul van Zeeland and the Dutch Ambassador in Brussels, 13.11.1953, in: F. PEEMANS, T. GROSBOIS, P.-E. HANQUET, Belgische diplomatieke stukken 1941-1960. Deel V-Politieke Integratie, Koninklijke Vlaamse Academie van België voor Wetenschappen en Kunsten, Brussels, 2009, pp.151-154.

44. J.W. BEYEN, Het spel en de knikkers, Een kroniek van 50 jaren, Donker, Rotterdam, 1968, pp.227-229. 


\section{Relance européenne: the exceptional tandem Spaak-Beyen}

The history of the relance européenne is the classic success story of Belgian-Dutch cooperation. But rather than the ultimate proof of their enduring partnership, we argue that it represents an unusual episode in the history of Belgian-Dutch cooperation, coinciding with the terms of two extraordinary pro-European and proactive Ministers of Foreign Affairs: Paul-Henri Spaak and Jan-Willem Beyen. ${ }^{45}$

It is hard to overestimate the role of Spaak in Belgian foreign and European policy. He not only redefined Belgium's European policy, he was also a driving force behind several European initiatives. Spaak's open style and close relations with subsequent US administrations contrasted sharply with the more ambivalent attitude of his predecessor van Zeeland, who was rather rigidly focused on the preservation of Belgium's independence. Van Zeeland's policies were rooted in classic conservative thinking, in which the preservation of economic and political independence through national sovereignty formed the primary objective of Belgian foreign policy. Indeed, Spaak departed from a similar worry about the position and autonomy of small states, but he drew diametrically opposed conclusions in comparison to his predecessors. Curtailing national sovereignty would not harm the interests of small member states, but expand their autonomy among 'the Six', on the condition - of course - that the big member states would be bound by the same rules - something that was more inherent in supranational integration than in any other form of multilateral cooperation.

From 1952 onwards, Spaak, in his capacity of opposition leader, led a strong campaign against the intergovernmental European policies of the Christian democratic Pholien government. This strengthened his domestic position, not in the least since it allowed him to deepen his already close relations across the Atlantic, the mighty and consistent supporter of supranational European integration. When Spaak became Foreign Minister in April 1954 (in a coalition of socialists and liberals), he did not hesitate to redefine his country's foreign policy in line with his own supranational convictions. Under Spaak's impulses, Belgium would soon say farewell to van Zeeland's more defensive European policies and transform into the European project's most faithful champion. ${ }^{46}$ Spaak marked the beginning of a steadfast proEuropean tradition in Belgian foreign policy.

Dutch European policy developed along completely different lines. With the benefit of hindsight, Beyen's Ministry can be labelled an aberration in the history of Dutch European policy, both within the broader context of the successive Drees cabinets (1948-1958), as well as with regard to the 'Atlantic primacy', which undisputably dominated the European policies of his predecessor Stikker (1948-1952) and his successor Joseph Luns (1956-1971). Beyen was not at ease with the fairly one-dimensional and rather easy Atlanticism, which was dominant in the foreign elite in The Hague. The Dutch mistrust of any form of continental cooperation that flew

45. Ibid., p.237.

46. R. COOLSAET, op.cit., pp.403-409; J.E. HELMREICH, op.cit., p.123. 
from the Atlantic primacy irritated him. Later he confessed that he despised the typical Dutch virtues in dealing with continental partners and concerts: 'stiffness, a fear to be screwed, no feeling for gestures, horrible' ${ }^{47}$ The fact that Beyen, during his term as Ambassador to Paris (after his Ministry), changed his religion from Protestant to Roman Catholic may be considered a telling action of a former Minister, whose Prime Minister (Drees), predecessor (Stikker) and successor on European dossiers (Ernst van der Beugel) were all vividly aware of one striking fact of life in the Europe of 'the Six'. The founding fathers of 'Little Europe' - Robert Schuman, Konrad Adenauer and Alcide De Gasperi -, without exception, had been Roman Catholics. Moreover, Roman Catholicism was the prevailing religion and culture in all member states of 'the Six', except from the Netherlands. ${ }^{48}$ 'Dutch exceptionalism' in little Europe simply was a matter of consequence rather than a deliberate choice.

This awareness ran parallel to a latent fear among policy-makers in The Hague of getting trapped in an oppressing continental 'Europe of the Vatican'. Against this background, Dutch governments in general were convinced that a close partnership with Belgium would not offer sufficient guarantees, as far as the Dutch interests within the framework of European integration were concerned. ${ }^{49}$

Under Drees and Stikker, the Netherlands had been very sceptical towards 'the Six'. Apart from Dutch 'minority feelings' in Little Europe, this largely French-orientated continental enterprise seemed difficult to reconcile with the traditional priorities of Dutch foreign policy: trans-Atlantic cooperation, global free trade and British participation in any European concert whatsoever. Beyen, who was not a member of a political party, saw things from a different angle. According to him, the oftenstressed opposition between supranational regional integration and Western multilateralism favouring free trade was nonsense. ${ }^{50}$ This conviction triggered him to launch the above-mentioned Beyen Plan, which outlined the subsequent steps towards a 'horizontal integration' of the economies of the Six resulting in a common market that would significantly contribute to the economic power of Western Europe and enable it to fend off the threats of communism and fascism, strengthening the West through regional, continentally oriented, bloc-building.

47. W.H. WEENINK, Johan Willem Beyen 1897-1976, Prometheus, Amsterdam, 2005, p.436.

48. D.U. STIKKER, Men of Responsibility. A Memoir, Harper and Row, New York, 1965, p.177; E.H. VAN DER BEUGEL, De ontwikkeling van Europa tot een eenheid - Economische aspecten, in: Vier maal Europa, 1959, pp.61-62.

49. Interview E.H. van der Beugel, in: A.G. HARRYVAN, J. VAN DER HARST, S. VAN VOORST, op.cit., p.59. As the later French Minister of Foreign Affairs, Maurice Couve de Murville, put it, the Dutch were in fact not to be considered 'continental Europeans'. See S. REYN, Atlantis lost: the American experience with de Gaulle (1958-1969), Unpublished thesis, Leiden, 2007, p.351.

50. On the contrary, Beyen had already concluded in 1944 that regional cooperation with a supranational character was more likely to achieve concrete results than the Wilsonian one world approach. 


\section{Preparing the relance}

As from late 1954, Monnet and Spaak cooperated to bolster a revival of European sector-integration after the EDC debacle. They worked on the extension of ECSC competences towards the sectors of energy and transport, and above all on the launch of a 'atomic community', which Monnet considered exceptionally suited to re-engage France in the integration process. However, in early April 1955, Monnet was unpleasantly surprised by confidential information from Bonn. The sector-integration sceptics under the leadership of Minister of Economic Affairs, Ludwig Erhard, had taken over the control over European dossiers and they were hostile towards Monnet's plan for an atomic community. The information Monnet got through his contacts in Bonn was unambiguous: the only chance for a cooperative West German attitude regarding his new project lay in a parallel re-launch of the common market, highly advantageous to Germany's export economy. ${ }^{51}$ Anticipating the ministerial meeting of 'the Six' scheduled later that spring, Monnet's economic aid Pierre Uri drew up a plan, in which he combined ideas about further sector integration with the project of a common market. Monnet 'hoped' this projet de déclaration 'could serve as a basis for a Benelux paper'. ${ }^{52}$ After all, it was quite unrealistic to launch a new initiative from Paris or Bonn after the EDC-debacle.

On April 22, Spaak and Monnet discussed the 'Uri note'. ${ }^{53}$ Spaak convinced Monnet that it was not opportune to dedicate only one page (out of five), inspired by the Beyen Plan of 1953, to the common market. According to Spaak, sector integration and horizontal integration (i.e. the common market) had to be presented as equal parts of a future Benelux memorandum. ${ }^{54}$ The following day, Spaak who in the meanwhile had obtained the backing of his Luxembourgish counterpart Joseph Bech travelled to The Hague to finalise the memo together with Beyen. In its revised version the 'Uri note' appeared acceptable to Beyen. The Dutch only insisted to keep the editorial responsibility as far as the part on the common market was concerned. Subsequently, Spaak and Beyen cooperated closely and produced the famous Beneluxmemorandum, which thus was based on the so-called projet de déclaration that Monnet and Uri had conceived in order to revitalise European sector-integration..$^{55}$

The ECSC member states discussed the Benelux-memorandum during the Conference of Messina (1-2 June 1955), and decided to set up an intergovernmental committee to study the feasibility of the plans for a European atomic community (Euratom) and a European common market, the European Economic Community

51. P. GERBET, La relance européenne jusqu'à la conférence de Messine, in: E. SERRA (ed.), Il rilancio dell'Europa e i trattati di Roma, Bruylant, Brussels, 1989, pp.78-79.

52. M. KOHNSTAMM, op.cit., p.69.

53. Politisches Archiv des Auswärtigen Amts, Berlin (PAAA), 2, 900, A9010, Vorschlag Monnet. Confidential, 14.04.1955.

54. M. DUMOULIN, op.cit., p.505.

55. J-C. SNOY ET D’OPPUERS, Le rôle du Benelux dans la relance européenne en 1955, in: Belgisch buitenlands beleid en internationale betrekkingen, Leuven, 1978, p.231; R. ROTHSCHILD, Un phénix nommé Europe. Mémoires 1945-1995, CRISP, Brussels, 1997, p.159. 
(EEC). Furthermore, they agreed that this committee had to be chaired by a 'political personality'. Shortly after the Conference, it was announced that it was Spaak who would fill the function of the chair of the committee. ${ }^{56}$

\section{Extraordinary momentum}

During the EEC and Euratom negotiations the positions of Belgium and the Netherlands diverged even more than during the EDC talks. Under Spaak's impulse, Belgium had left its intergovernmental stance and had become a passionate supporter of a supranational Europe and sector-integration following the ECSC model. In contrast to the Dutch government, wherein Beyen's influence was far less profound, the cabinet continued to opt for a technocratic economic integration approach. Ironically, while the divergence in positions of both states was almost starker than ever, this time this did not result in dominant sentiments of mutual suspicion, as had been the case in earlier phases of the European negotiating processes. The reason for this could be found in the atypical approaches Spaak and Beyen took with regard to the classic Belgian-Dutch tension in relation to European integration. In a way, Beyen could be considered more of a 'Belgian' than his more Atlantic peers, while the Atlantic Spaak could be portrayed as more of a 'Dutchman' when compared to his predecessors.

Be this as it might, familiar patterns of tension in the Belgian-Dutch relation soon resurfaced during the negotiations. Again, Belgium adopted the more consistent line of the two, steadfastly striving for the paradoxical goals of UK involvement in the talks and a strengthening of the supranational organisation of Europe at the same time. In sharp contrast to the early 1950 s, and also nurtured by negative experiences in the Benelux (in which an executive institution was still lacking), Brussels now favoured a stronger supranational European executive and, consequently, pleaded in favour of more rather than less sector-integration. Yet, mainly on the basis of the above-mentioned strategic reasons with regard to German and Dutch commitments to the relance, Spaak was very receptive to a 'horizontal' form of integration too and carefully encapsulated this notion in the Belgian stance..$^{57}$

The Netherlands, for their part, remained very hesitant, and sometimes almost even outright hostile towards the relance. In spite of Beyen's constructive position on the matter, scepticism remained the dominant sentiment in the Dutch cabinet. ${ }^{58}$ As became obvious after Beyen's forced departure resulting from a cabinet crisis in the second half of 1956. With the official treaty negotiations just underway, the Netherlands quickly restored its traditional European policy under Beyen's successor van der Beugel and returned to the traditional Dutch principles in European politics.

56. M. KOHNSTAMM, op.cit., pp.13-14 and 40-41.

57. Ibid., pp.181-187.

58. Interview E.H. van der Beugel, in: A.G. HARRYVAN, J. VAN DER HARST, S. VAN VOORST, op.cit., p.48. 
The deep desire to flee from continental concerts via Atlantic bonds of free trade ran free again. However, and to the frustration of many Dutch policy makers, this 'restoration' proved to be too late to influence the on-going negotiations.

\section{The reality of 'little Europe'}

Shortly after the Treaties of Rome had been signed, discussions started about how the 'Six' should relate to a Free Trade Area (FTA), a follow-up project to the earlier British attempt to launch an FTA within the framework of the EEC negotiations (dating back to the autumn of 1956). In the wake of the unfolding negotiations on the FTA, the relics of the close Spaak-Beyen cooperation that characterised the first stages of the relance had vanished. Belgium even got the feeling that the Dutch wished to slow and water down the EEC and silently considered the signing of the Rome Treaties - the result of successful Benelux-cooperation - 'a mistake'. ${ }^{59}$

The return of euro-scepticism in The Hague after the leaving of Beyen resulted in a paradoxical combination of revisionist and conservative objectives in Dutch European policies. In relation to enlargement, the Netherlands could be considered revisionary. It viewed its close ties with its Anglo-Saxon friends in Washington and London as an absolute priority, also with regard to European cooperation. It therefore strongly promoted EEC enlargement. In relation to the deepening of integration, however, the Netherlands now followed a conservative policy line. The Dutch position was characterised by an allergy to the slightest tendency towards a more independent international and political role for 'little Europe'. If there had to be some sort of a political community at all, it definitely would have to be an Atlantic community and by no means a continental undertaking. This combination of revisionism and conservative elements resulted in a minimalistic approach: European integration had to remain as technocratic as possible, boiling down to a mere promotion of free trade. Joint Western politics were the exclusive domain of NATO.

It should be stressed, however, that the Dutch objective to keep European cooperation as depoliticised as possible was in essence very political. Due to its uncontested image as the champion of free trade within 'the Six', it has often been overlooked that the Dutch government was willing to subordinate its economic (trade) interest to the political objective of an Atlantic community. Therefore the boost for 'little Europe' as a result of the signing of the Treaties of Rome was not quite a

59. Belgian Ministry of Foreign Affairs, J. van der Meulen, Permanent Representative of Belgium to the EEC, to P. Wigny, Minister of Foreign Affairs, 15.04.1959, in: G. KURGAN-VAN HENTENRYK, I. SIRJACOBS, op.cit., pp.398-401. 
satisfactory development in Dutch eyes, to say the least. ${ }^{60}$ In the autumn of 1958 , with the FTA talks on the brink of collapse (mainly due to fierce resistance from France and the EEC Commission), van der Beugel appealed to Washington that 'the friends of trade liberalism within the EEC were in rather desperate need of assistance' and warned the Americans of 'a split between the EEC and the rest of the OEEC countries', which 'could endanger [...] NATO' ${ }^{61}$ It had been to no avail. The failure of the FTA in the autumn of 1958, with American consent, deprived the Netherlands of its last escape route out of the stuffy 'Six'. The Dutch were trapped in 'little Europe'.

\section{Resistance against a Gaullist Europe}

In the summer of 1959, President Charles de Gaulle proposed a plan to advance political integration among 'the Six' on an intergovernmental basis. Dutch Foreign Minister Josef Luns rejected it out of hand, arguing that the current institutional setup of the EEC sufficed. Within the cabinet, he argued that every political formation that could be directed against the Netherlands' Anglo-Saxon partners would be insane, jeopardise cooperation within NATO, and thus harm the most vital interests of the Netherlands. ${ }^{62}$ West German reluctance would eventually thwart de Gaulle's first design for a European Political Union (EPU). However under new impulses of de Gaulle, 'the Six' soon started new consultations on the institutionalisation of political cooperation. These were accelerated after the Franco-German rapprochement on the issue during the summer and autumn of 1960.

Initially, Belgium and the Netherlands reacted very differently to de Gaulle's plans. In sharp contrast to Dutch hostility, the Belgian Minister of Foreign Affairs, Pierre Wigny, was overall positive. The Belgian Minister was careful not to turn down the French suggestions, as a suchlike action could easily harm the EEC and the Belgian interests therein. Moreover, he expected that a 'constructive opposition' held more potential to alter the French proposals rather than simply rejecting them out of hand. ${ }^{63}$

60. N.P. LUDLOW, Too close a friend? The Netherlands and the first British application to the EEC, 1961-1963, in: N. ASHTON, D. HELLEMA (eds), Anglo-Dutch relations since 1780, Amsterdam University Press, Amsterdam, 2001, p.230. For the principal attitude of the Netherlands in relation to Atlantic primacy in European integration, compare J. C. VOORHOEVE, Peace, Profit and Principles: A Study of Dutch Foreign Policy, Martinus Nijhoff, Leiden, 1985, pp.162-163 and pp.191-192.

61. DEPARTMENT OF STATE PUBLICATIONS, Foreign Relations of the United States, 1958-60, 7,2, Washington, 1993, pp.78-80 and p.150.

62. A.E. KERSTEN, Luns. Een politieke biografie, Boom, Amsterdam, 2010, p.270; J. VANKE, An Impossible Union: Dutch Objections to the Fouchet Plan, in: Cold War History, 2(2001), p.97.

63. BelArch, Unknown, 18684 I. 
Between 1958 and 1961, the subsequent Christian-democratic governments led by Gaston Eyskens displayed a more modest version of Spaak's passionate quest for a supranational political Europe. In some aspects the Eyskens governments even harked back to van Zeeland's Euro-sceptic positions in the early 1950s. In addition, the independence of Belgian Congo fostered a pro-French feeling in Brussels, reinforced by the highly critical response to the Belgian handling of Congo from the UK and the US. ${ }^{64}$

For Belgian policy-makers, the negative attitude of the Netherlands towards the EPU-plan of de Gaulle, once again was a clear sign of the country's 'British vision' with regard to European integration, ultimately aimed at creating a large free trade area based on technocratic rules and without any political framework. Together with Luxembourg and Italy, Belgium tried to reconcile the Dutch and French positions. They had little success. The Dutch grew increasingly irritated by the lack of Belgian solidarity. ${ }^{65}$

In February 1961, the heads of state and government of 'the Six' met to discuss the proposals of de Gaulle. Luns, who strongly pleaded for British participation during the talks (the préalable anglais), got completely isolated yet refused to swallow his words. Due to the continuing Dutch resistance, 'the Six' decided to set up a commission of national representatives in order to prepare proposals for EPU, the socalled Fouchet Commission. Even though the establishment of this commission and the inherent delay in the negotiations could be considered a victory for the defensive Dutch delegation, Luns remained painfully isolated. His position would soon become impossible. That is to say, as long as the UK would not take any concrete steps towards EEC membership. Moreover, the opportunistic Dutch strategy, which combined a desire for British accession with parallel pleas for further supranational integration within the EEC, seemed utterly 'illogical', as the French would emphasise time and again. ${ }^{66}$

The ambiguous Dutch position was the outcome of an evolution in Dutch European policy that resembled the Belgian shift in European policy five years earlier under Spaak. There were some important differences however. The 'Dutch turn' in favour of supranational integration was a product of the European conservatism that had re-emerged in The Hague after the departure of Beyen, when traditional euroscepticism was combined with a rather opportunistic (anti-Gaullist) strategy to weaken EPU plans.

But the Dutch could not foster any illusion: the 'other Five' showed a willingness to go along with the Gaullist initiative, there was no British EEC membership bid and de Gaulle could even count on Monnet and the American administration to support

64. R. COOLSAET, op.cit., pp.431-441.

65. BelArch, Unknown, $18684 \mathrm{I}$.

66. NArch, 2.05.118, 1391, Beyen 379, 16.09.1960. Archives of the French Ministry of Foreign Affairs (FArch), Documents Diplomatiques Français (DDF), 1961 (1993), pp.192-193. 
his initiative. ${ }^{67}$ In reaction, an anxious and divided Dutch government opted for a pragmatic stance and tried to slow down discussions in the hope circumstances would soon change for the better. However, already in the spring of 1961, the Dutch delegation in the Fouchet Commission was forced to give in and dropped the préalable anglais. ${ }^{68}$ But during the summer of 1961, the odds changed on two fronts. First, London, on strong American urging, announced its decision to apply for full-fledged EEC membership. Second, Spaak returned as Belgian Minister of Foreign Affairs.

After Spaak's return as Foreign Minister in April 1961, the Belgian position in the Fouchet-negotiations changed. Even though his position was quite close to the Dutch line, Spaak initially tried to reconcile the Dutch and French positions (until the end of July 1961). ${ }^{69}$ Yet, the mere arrival of Spaak helped the Netherlands to crawl out of its isolated position. It allowed The Hague to hide behind Spaak's initiative for a mildly sceptic Benelux memorandum regarding the whole Fouchet undertaking. ${ }^{70}$ The British application for EEC membership in August 1961 further strengthened the position of the Dutch delegation, which had been completely outmanoeuvred by the early summer of 1961 . Eventually, Spaak would take over the lead in the fight against Fouchet. ${ }^{71} \mathrm{He}$ shared the Dutch fears with regard to de Gaulle's plans, and the challenge they posed to American leadership and to the position of the small members of 'the Six'. Spaak reformulated the Belgian position and joined the Dutch plea for the direct and immediate inclusion of Britain in the negotiations on EPU.

The convergence of their respective positions led to a highly effective BelgianDutch ad hoc coalition. In confidential talks with Luns, Spaak argued that it would be particularly dangerous for small countries 'to fall under the political leadership of un pareil Machiavel', referring to de Gaulle. Spaak added that he felt closer to the 'Anglo-Saxons' than to the French and Germans. For The Hague, this cleared the way for joint cooperation in the wreckage of the Fouchet plan. ${ }^{72}$

67. NArch, 652, fiche 1534, MR, 20.01 and 03.02.1961; compare NArch, 2.05.118, 30154, van Houten to S., 07, 21 and 25.09.1959 and 12.11.1959.

68. NArch, 652, fiche 156, MR, 17, 21 and 28.04.1961.

69. HAEU, MK, Dagboeken Max Kohnstamm, Diary 16; Unknown, Spaak is mediating in European rift, in: New York Times, 09.06.1961.

70. In this memorandum, both countries agreed to revive European integration in the political sphere on the condition that the accomplishments of the EEC would be respected, starting with an experimental phase, setting up a small secretariat only and inviting the United Kingdom (Benelux memorandum, 15.06.1961). The Netherlands, however, remained suspicious about aspects of the memorandum, such as the explicit support for a new secretariat and the ambiguous Belgian phrasing as if the UK's association with the Fouchet talks was only 'desirable'. See BelArch, Unknown, $18684 \mathrm{I}$.

71. BelArch, Unknown, 18684 I; M. SEGERS, De Gaulle's Race to the Bottom: The Netherlands, France and the Interwoven Problems of British EEC Membership and European Political Union, 1958-1963, in: Contemporary European History, 19(2010), pp.126-130.

72. BelArch, 18684 I. Especially, after de Gaulle unilaterally had hardened the French position in January 1962 and Britain had communicated its wish to join the Fouchet talks in the early spring of 1962. See also M. SEGERS, op.cit., pp.128-130; NArch, Archive Luns, 237, Summary of BelgianDutch Ministerial talks, 17.03.1962. 
Already by the end of July 1961, Spaak had taken over the leadership in the Belgian-Dutch anti-Fouchet campaign, striving for a more communitarian version or, alternatively, to the inclusion of the UK in order to form a counterweight to the ParisBonn axis. ${ }^{73}$ Eventually, it was Spaak - who had got extremely irritated by de Gaulle's continuous rejection of his alternative EPU plans -, who wrecked the Fouchet Plan on 17 April 1962. With the British EEC membership bid on the table and the full support of his Dutch counterpart, Spaak put forward the préalable anglais as a conditio sine qua non for any advance in the EPU talks. This proved unacceptable in the eyes of the French. ${ }^{74}$ Spaak used the Dutch arguments regarding a possible weakening of American leadership and the role of NATO, by which he provoked the French Foreign Minister's utter disdain. ${ }^{75}$

Although Belgium and the Netherlands worked closely together in the battle against the Fouchet plan, this did not imply that their respective visions of European integration converged. On the contrary, fundamental differences persisted. Spaak remained negative about any approach that considered the EEC as a mere free trade area. He sincerely guarded supranational integration and the community method.

The Netherlands continued to repeat the argument that European political integration should be rejected completely as long as economic integration had not been fully materialised. Belgium, on the contrary, wished to deepen political integration in parallel to the process of economic convergence, assuming that such a route would safeguard the position of small members more adequately. These fundamental differences came to the fore when Spaak started a charm offensive in September 1964, in which he rallied for new talks about political integration. Spaak now softened his position towards Gaullist France in order to keep some options open for any kind of political deepening of the integration process that he desired so strongly. ${ }^{76}$ The confrontational European policies of de Gaulle had driven Belgium and the Netherlands in one another's arms, but this certainly did not imply a meeting of minds.

During the Presidency of de Gaulle, the General's confrontational politics within the EEC became the rule rather than the exception. De Gaulle's first veto against British EEC accession and the subsequent highly controversial Franco-German Treaty of Friendship in early 1963 build historic highlights of this. These shocks were followed by de Gaulle's direct confrontation with the European Commission through his famous policy of the empty chair during the negotiations concerning the implementation of the Common Agricultural Policy (CAP) in 1965. Moreover, the general renewed his veto against British EEC accession in 1967. As a result of these Gaullist provocations and obstructions, patterns of alliance formation within the EEC against France's European policy were plentiful, with Belgium and the Netherlands figuring

73. BelArch, 18684 I; HAEU, MK, Dagboeken Max Kohnstamm, Diary 16; Paul-Henri Spaak. Note about European political unification, 16.06.1964.

74. FArch, DDF 1962, 1(1998), pp. 433-434.

75. BelArch, 18684 I., Paul-Henri Spaak. Reunion of the Ministers of Foreign Affairs, 21.03.1962 and Internal document, 30.04.1962.

76. Unknown, in: Frankfurter Rundschau, 11.09.1964; See also M. DUMOULIN, op.cit., pp.639-640. 
as the most outspoken opponents of de Gaulle and the most fervent supporters of British EEC membership.

In reaction to the intense (intergovernmental) power political tendencies within the integration process unleashed by de Gaulle's policies during the 1960s, the Belgian-Dutch conviction of the necessity for British accession in order to create a counterweight to Franco-German dominance grew stronger. ${ }^{77}$ This principled (antiGaullist) objective clearly prevailed over direct Dutch economic interests, as it was of the utmost importance that it was made unmistakably clear that there were 'limits to the continental orientation that France wanted to force upon us' ${ }^{78}$ In light of the fanatic Dutch resistance, Belgian diplomacy came to the telling conclusion that the Netherlands had in fact been opposed to the form that the European integration process had taken. ${ }^{79}$

\section{Conclusion}

In this article we have examined Belgian-Dutch relations during the early stages of the European integration process. In line with the 'revisionist' literature, in which the successes of the Belgian-Dutch tandem have been demystified, we argue that tenacious disagreement was as characteristic of Belgian-Dutch partnership as were its famous concerted lobbying successes. A shared reflex against a possible FrancoGerman directorate characterised Belgian-Dutch relations in the early stages of the European integration process, although it was driven by different motives.

For the Netherlands, it reflected an essentially Atlantic reasoning. Belgium on the other hand continued careful balancing of its position vis-à-vis the Franco-German axis, aimed at striking a balance between too close relations with both countries and avoiding outright confrontations with Paris and Bonn. As a result, the Belgian-Dutch partnership was largely reactive and tended to elude behind the façade of the formal framework of Benelux cooperation.

Moreover, mutual suspicion remained strong. In the Netherlands, suspicion was nurtured by the assumed tendency in Belgian foreign policy of almost naturally tilting towards France. In Belgium, policy-makers were wary of the rather rigid (technocratic-economic) Dutch view on the Europe of 'the Six' and the country's ardent Anglo-Saxon preferences with regard to European integration. This, however, did not prevent both countries from (very effectively) joining forces at times when their respective vital interests were at stake. The findings in this article confirm and reinforce the existing revisionist trend with respect to Benelux cooperation in the early stages of European integration. Three points stand out.

77. BelArch, Unknown, 7157 I; Joseph Luns, in: Süddeutsche Zeitung, 05.05.1965.

78. NArch, 2.05.118, 16192, Sous-chef DES to DGES. Gedragslijn bij Frans veto, 09.08.1967, pp.1-3.

79. BelArch, Unknown, $18684 \mathrm{I}$. 
First, the Belgian-Dutch partnership was, with the exception of the Spaak-Beyen period, not the constructive and proactive engine of European integration it has been often pictured to be. The sparse episodes of constructive Belgian-Dutch cooperation can be attributed to coincidental circumstances, namely the simultaneity of the terms of two pro-European and influential Ministers of Foreign Affairs. Second, BelgianDutch cooperation lacked a structural convergence of interests and points of view within the framework of European integration, implying an absence of a shared longterm vision on cooperation. Even if the institutionalisation of the Belgian-Dutch partnership may have been a perfectly rational thing to do (in order to pursue congruent goals of the 'comparable' Low Countries), this did not square at all with the actual positioning of Belgium and the Netherlands in matters of European integration. As shown, even the most heroic successes of the Belgian-Dutch partnership in the 1950s (the Benelux memorandum) and the 1960s (the Belgian-Dutch torpedoing of the Fouchet plan) first and foremost were the result of short-lived coalitions, largely initiated in reaction to circumstances and impulses beyond the reach of Brussels and The Hague. These coalitions only temporarily transcended the deep-rooted suspicion between Brussels and The Hague. Third, doubts can be cast on the often-celebrated pro-European tradition of both countries, especially in the case of the Netherlands. The latter country remained wary of the 'little Europe' of 'the Six', even after the signing of the Treaties of Rome. It continued to long for an encompassing Atlantic community, a distant ideal. Ironically, Washington repeatedly turned out to be little Europe's strongest supporter during the 1950s and early 1960s, leaving The Hague in the difficult position of a staunch but rather isolated Atlantic partner in European Affairs. This, in turn, had negative repercussions regarding (continental) BelgianDutch relations.

Led by its influential and proactive Foreign Minister Paul-Henri Spaak, Belgium understood that it had to change its tactics in order to exploit the American support for a Franco-German Europe. As a result, it adopted an outspoken pro-supranational European policy from 1954 onwards. Although the Netherlands shared the view that a flexible pro-supranational European policy held tactical benefits, it never internalised this policy-shift to the extent Belgium did. This sowed new seeds of mutual distrust. Parallel political interests in matters of European integration never led to a deepening of Belgian-Dutch bloc-building and/or integration. This happened not so much because of diverging economic interests, but rather as a result of the incompatibleness of the Belgian desire to balance Paris and Bonn - which laid the groundwork of a strong tradition of pro-supranational European policy - with the Dutch vision of Atlantic community, based on the maritime desire to escape from continental constrictions and grounded in the conviction that Atlantic free trade was the classic instrument to pursue that. European integration was desirable as long as it served the ultimate goal of making European politics and Atlantic trade liberalism identical phenomena. In other words, the Dutch strongly preferred to keep European integration limited to technocracy in service of free trade - something quite strange to the Belgians. 


\section{Geteiltes Zypern}

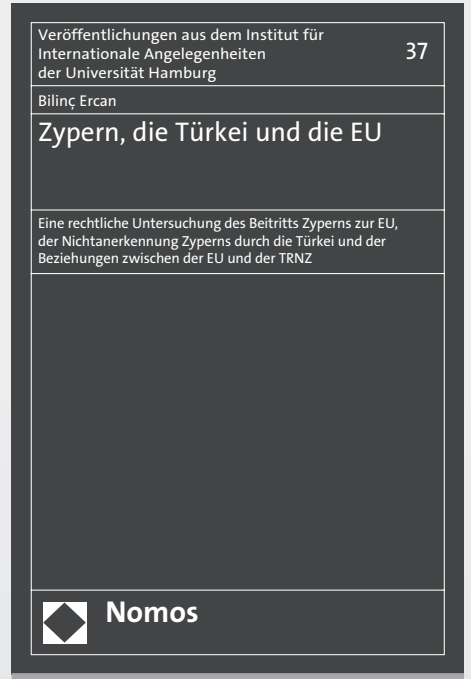

$\sqrt{2+20}$

\section{Zypern, die Türkei und die EU}

Eine rechtliche Untersuchung des Beitritts Zyperns zur EU, der Nichtanerkennung Zyperns durch die Türkei und der Beziehungen zwischen der EU und der TRNZ Von Bilinc Ercan

2012, 257 S., brosch., 69,-€

ISBN 978-3-8329-7608-8

(Veröffentlichungen aus dem Institut für Internationale Angelegenheiten der Universität Hamburg, Bd. 37)
Seit dem EU-Beitritt Zyperns im Mai 2004 weichen die rechtliche und die faktische Situation auf der Insel weiterhin voneinander ab. Rein rechtlich ist die gesamte Insel Mitglied der EU geworden, faktisch jedoch nur der zyperngriechische Süden.

Diese Arbeit beschäftigt sich mit der Frage, wie diese Situation völker- und europarechtlich, aber auch nach zypriotischem Verfassungsrecht zu bewerten ist. Sie kommt zu dem Ergebnis, dass der EU-Beitritt Zyperns rechtliche Probleme aufweist, die dauerhaft nicht ungelöst bleiben sollten. Ein weiteres Augenmerk dieser Arbeit gilt den damit einhergehenden Folgeproblematiken: Einerseits der Frage der Nichtanerkennung Zyperns durch die Türkei, andererseits der Frage nach dem Status der Türkischen Republik Nordzypern (TRNZ) im Lichte aktueller Entwicklungen. 